\title{
Changing Sides: The Failure of the Wrestling Community's Challenges to Title IX and New Strategies for Saving NCAA Sport Teams
}

\author{
Bradley David Ridpath, Athena Yiamouyiannis, \\ and Heather Lawrence \\ Ohio University \\ Kristen Galles \\ American Bar Association
}

\begin{abstract}
The relationship of intercollegiate athletics and the federal Title IX statute has been the subject of significant concern and academic inquiry. This article explores the legal and legislative history of Title IX and the statute's impact on intercollegiate athletic programs and practical solutions for compliance. The article is broken into three distinct parts. Part I details a brief history of Title IX congressional, judicial, and regulatory involvement/enforcement over the past 36 years. Part II examines Title IX's application in practice with regard to public institutions and athletics. In Part III, the researchers present recommendations to wrestling programs and other men's teams concerning the economic realities of intercollegiate athletics. Specifically the researchers examine the wrestling community's legal and legislative challenges and explain how colleges' economic decisions and zeal for competitive teams at the "revenue sports" level are at the core of wrestling's dilemma rather than the law itself. The researchers also suggest more constructive solutions for preserving and expanding athletic opportunities for all without cutting men's sports programs. In particular, they argue that instead of attacking Title IX and women's sports, the wrestling community should form alliances with women's teams and their advocates to reverse the reallocation of resources in the college athletics arms race.
\end{abstract}

The perception that Title IX and gender equity requirements are responsible for the loss of hundreds of intercollegiate wrestling programs is widely accepted by many who are affiliated with the sport (Benson, 2007; Hughes, 1999; Ridpath, 2007a, b). On the surface, the evidence appears to support that contention, as some athletic directors and university presidents over the past two decades, in an effort

Ridpath, Yiamouyiannis, and Lawrence are with Ohio University, Recreation and Sport Sciences, Grover Center E173, Athens, OH, 45701. Galles is the co-founder of the Legal Institute for Gender Equity in Athletics. 
to comply with Title IX requirements, have chosen either to eliminate men's athletic programs or reduce them to the club level. The number of NCAA wrestling programs in NCAA Divisions I, II, and III dropped from 234 to 129 over the course of an NCAA participation study conducted from 1982 to 2000 (Benson, 2007). The trend continued with the loss of several wrestling programs in 2007 including the University of Oregon's nationally competitive program, ostensibly for gender equity reasons. Whether this is true or not is open to debate because Oregon proceeded, at the same time, to add the sport of baseball. (N. Tublitz, personal communication, July 16, 2007; Oregon to reinstate baseball, drop wrestling, 2007). In addition, fifty-five men's NCAA Division I gymnastics programsroughly $69 \%$ - were dropped during a time span similar to that of the NCAA study (Ridpath, 2007a, b). The NCAA Division I membership, which typically includes the largest colleges and universities in the nation, along with those that play in the Football Bowl Subdivision (FBS; formerly Division I-A) and the Football Championship Subdivision (formerly I-AA), continues to argue that men's programs are being eliminated for purposes of promoting gender equity (Benson, 2007).

In late 2006, James Madison University (JMU) announced the elimination of 10 varsity athletic teams, including 7 men's teams (archery, cross country, gymnastics, indoor/outdoor track, swimming, and wrestling) and 3 women's teams (archery, fencing, and gymnastics; Brady, 2007). This is another in a long history of athletic teams, most notably wrestling, being eliminated under the guise of Title IX compliance (Suggs, 2005). Some athletes from these teams challenged the cuts by filing a lawsuit against both JMU for eliminating the teams and the U.S. Department of Education (DOE; Equity in Athletics v. Department of Education, et al., 2007). The United States District Court for the Western District of Virginia denied the injunction, and the cuts went into effect in July 1, 2007. The United States Court of Appeals for the Fourth Circuit upheld the decision in August 2008. (Equity in Athletics v. Department of Education, et al.).

The James Madison University case is one of the latest in a series of spirited but unsuccessful suits filed by the National Wrestling Coaches Association (NWCA) and the College Sports Council (CSC) against the DOE after several colleges eliminated varsity men's wrestling programs. The lawsuits challenged DOE's implementation of Title IX of the Education Amendments of 1972 (CSC v. DOE, 2006; CSC v. General Accounting Office, 2003; CSC v. Paige, 2003; NWCA v. DOE, 2003).

The NWCA along with wrestlers who have had their sport eliminated, argued, and continue to argue, that DOE's interpretation of Title IX -including its 1979 Policy Interpretation and its 1996 clarification on that Policy Interpretation's three-part test for measuring participation equity-discriminates against men and causes colleges to eliminate men's varsity college teams. In effect, they claim "reverse" discrimination and blame Title IX for the loss of a variety of men's athletic teams, including wrestling.

Part I of this article details the history of Title IX and intercollegiate athletics at public institutions. It includes the long history of congressional, judicial, and regulatory challenges to the law. This history demonstrates that the wrestling community's arguments are not new; rather they are part of a 36-year battle against 
Title IX and athletic equity. Part II examines Title IX's application in practice. It further details the wrestling community's most recent legal and legislative strategies and explains why their factual and legal bases have been consistently denied. In Part III, the authors explain how the loss of men's programs is related more to institutional decisions to focus on revenue generating sports such as men's football and basketball than to meet Title IX requirements. These economic decisions, arguably, are the root causes of wrestling's problems. In Part III the authors also present what may be more realistic, constructive solutions to the problems faced by wrestlers and athletes in other men's programs. Specifically, the researchers argue that instead of challenging Title IX and women's sports, the wrestling community should form alliances with Title IX advocates and other supporters of women's programs to reverse the flow of resources in college athletics' major sports arms race, safeguard men's minor sport teams, and work to expand opportunities for women, including the expansion of teams in women's wrestling.

\section{Part I: History of Title IX and Congressional Intent}

In 1972, 170,384 men played varsity college sports under the auspices of the NCAA - a group that had governed and provided national championships for men's intercollegiate athletics since 1906 (NCAA, 2007d). At the same time, only 29,977 women played varsity college sports, primarily under the auspices of the American Intercollegiate Athletic Association for Women (AIAW; NCAA, 2003, p. 13-14). Many schools failed to offer any women's sports at all, and those relatively few female athletes who were fortunate enough to compete still received less support than their male counterparts. Compared with athletes on the men's teams, women typically received inferior equipment, uniforms, facilities, travel accommodations, and coaching support, to name only a few areas of unequal treatment. This discriminatory situation preceded the NCAA's involvement with women's sports (Crowley, 2006; NCAA, 2007d).

The passage of Title IX was supposed to end discrimination in all federally funded education programs-including athletics. While the law succeeded in many ways, men's athletics was now required to share already limited resources with expanding women's programs. Progress toward gender equity, consequently, was often perceived by men as a threat to their own welfare.

This is ironic because the statute was not aimed specifically at athletics. In fact, many did not see Title IX as an athletics-specific piece of legislation and least of all as something that, in the name of equity, could negatively impact men's programs. This misunderstanding of the law by the public led to many of the misguided attacks Title IX from the initiation of this legislation to the present day. A review of this history demonstrates that Congress fully considered-and rejected-a variety of counter arguments at the time Title IX was passed. The courts have done the same during the intervening years (Lopiano, 2001). This helps to explain why wrestling advocates keep losing their legal challenges to Title IX and why many researchers suggest it is time for the wrestling community to try something new. 


\section{The 1970s-Title IX and Its Regulations}

Congress passed Title IX in 1972. Its primary provision consistently states:

No person in the United States shall, on the basis of sex, be excluded from participation in, be denied the benefits of, or be subjected to discrimination under any education program or activity receiving Federal financial assistance. (20 U.S.C. $\$ 1681-1688,1972$ )

Given the broad scope of this language, Congress directed the executive branch to issue regulations to more thoroughly explain the requirements of the law. (20 U.S.C. §1682, 1972). The U.S. Department of Health, Education, and Welfare (HEW) published draft regulations for public comment in June 1974. The NCAA, the College Football Coaches Association (CFCA), and other men's sporting groups opposed the application of the law to athletics. They lobbied HEW to change the regulations, and they lobbied Congress to reject them. However, during congressional hearings on the matter, HEW Secretary Caspar Weinberger noted that the plain language of Title IX covers all educational programs. Congress did not write the statute to exclude athletics, football, or any other program, so the regulations could not exclude them.

Football advocates then tried to convince Congress to amend Title IX to exclude athletics. When that failed, they lobbied to exempt sports that produced gross revenue (notably not net revenue or profits). Their goal was to exempt football from Title IX. (Tower Amendment submitted on May 20, 1974, 120 Cong. Rec. 15,322-15,323, 1974). Congress refused to do it. Instead, it adopted a compromise amendment offered by Senator Jacob Javits (R-New York) that was intended to recognize that some sports cost more than others to operate so that equal treatment did not necessarily mean equal funding. It specifically directed HEW to issue Title IX regulations that included: "with respect to intercollegiate athletic activities, reasonable provisions considering the nature of particular sports" \{(Javits Amendment, Sen. Conf. Rep. No. 1026, 93rd Cong., 2nd Sess. 4271 (1974)\}.

Over the next year, HEW received more than 10,000 comments on Title IX regulations - most of them related to athletics. (Title IX basics: Breaking down barriers, 2008, p15, I1). After revising the regulations, HEW submitted them for President Ford's signature on May 27, 1975, and then submitted them to Congress for final review (40 Fed. Reg. 24,128, June 4, 1975). At that time, federal law mandated that Congress have an opportunity to review and comment on such regulations before they could go into effect. If Congress believed the regulations failed to reflect statutory intent, it could pass concurrent resolutions rejecting them in whole or in part $\{($ General Education Provisions Act, Pub.L. 93-380, 88 Stat. 567, as amended \$20 U.S.C. 1232(d)(1)\}.

Congress took this obligation seriously and held several days of hearings over the spring and summer of 1975. Men's sporting interests dominated the testimony. Their congressional supporters submitted several resolutions to reject the regulations entirely, to exclude athletics, or to exclude "revenue-producing" sports. They argued that the regulations required "quotas" and constituted "reverse discrimination" - essentially the same arguments still made today. Title IX supporters countered that the regulations did not promote reverse discrimination 
against males but instead stopped the preferential treatment those males had always enjoyed (Hearings on H.Con.Res. 330). Once again, this legislative history provides insight into reasons for the failure of the wrestling community and others in more recent times. Their appeals have been unsuccessful, in part, because they used the same arguments as those employed by football and wrestling coaches in front of Congress in the 1970s. Congress fully considered and rejected each of those arguments at that time. It is not surprising that the Courts similarly reject them today.

\section{Early Court Challenges}

The legislative arena was not the only venue for the Title IX debate. The NCAA filed a lawsuit against HEW that argued that the regulations (1) exceeded the authority of the statute by covering athletics at all, (2) established sex-based quotas, (3) were unconstitutionally vague, and (4) were arbitrary and capricious under the Administrative Procedure Act (NCAA v. Califano, 1978). The Western District of Missouri Court dismissed the lawsuit for lack of standing (NCAA v. Califano). By the time the appellate court reversed the decision, other legal actions were in the works to challenge Title IX, and the NCAA began the takeover of women's sports from the AIAW to assuage members' fears that separate governance structures could be seen as violations of Title IX (Crowley, 2006).

Schools themselves took up the charge in the late 1970s, arguing that their athletic programs did not have to comply with Title IX because the programs themselves did not receive direct financial assistance from the federal government. They sued HEW to prevent it from investigating their programs and from withholding federal funding (Bell v. Dougherty, 1982; Bennett v. West Texas State University, 1986; Department of Education v. Seattle University, 1982; Dougherty County School System v. Harris, 1980; Isleboro School Comm. v. Califano, 1979; Junior College Dist. of St. Louis v. Califano, 1979; North Haven Board of Education v. Bell, 1982; Othen v. Ann Arbor School Board, 1981; Romeo Community Schools v. HEW, 1977; Seattle University v. HEW, 1980; Wright v. Columbia University, 1981). HEW insisted that if a school received any federal funding, then all of its educational programs, including athletics, were covered by Title IX (Title IX basics: Breaking down barriers, 2008.). These legal battles delayed enforcement of Title IX in athletics. The debate was clearly destined for the U.S. Supreme Court.

In July 1976, Grove City College refused to sign the Assurance of Compliance required by 45 C.F.R. 86.4(a) now 34 C.F.R. 106.4(a), arguing that it did not receive federal financial assistance and thus was not covered by Title IX. HEW argued that the school received such funding through the federal tuition grants and loans paid to its students. In November 1978, Grove City filed a lawsuit to enjoin HEW from requiring Title IX compliance as a condition for providing grants and loans to its students. The U.S. Supreme Court eventually sided with Grove City and held that Title IX applied only to educational programs that actually received federal funds - and not to institutions as a whole (Grove City College v. Bell, 1984).

The Supreme Court's opinion caused DOE to stop all Title IX athletics investigations in their tracks. OCR dismissed hundreds of administrative complaints. 
Courts dismissed several pending cases. (Bennett v. West Texas State University, 1986; Haffer v. Temple University, 1981; O'Connor v. Peru State College, 1984). Title IX remained virtually unenforced until Congress passed the Civil Rights Restoration Act of 1987, which clarified that Congress intended Title IX to apply to an entire school if any of its programs or activities receive federal funding. (20 U.S.C. §1687). The law finally went into effect in 1988-16 years after Title IX's enactment.

\section{Part II: Wrestling and Title IX}

\section{The 1990s-Private Enforcement}

Female athletes finally began to fight for their rights under Title IX in the early 1990s, some 20 years after the law's passage. They sued Colgate University, Indiana University of Pennsylvania, Colorado State University, and Brown University after the schools eliminated their athletic teams (Cohen v. Brown University, 1992; Cook v. Colgate University, 1992; Favia v. Indiana University of Pennsylvania, 1993; Roberts v. Colorado State University, 1993). These cases applied the 1979 Policy Interpretation on Title IX and Intercollegiate Athletics for the first time. The case against Brown University illustrates the arguments made by institutions and later the NWCA.

The Cohen v. Brown University litigation is one of the landmark cases with regard to Title IX enforcement. In 1990-91, Brown University sponsored 31 varsity sports, including 16 sports for 566 men (63.3\% of the athletes at Brown) and 15 sports for 328 women (36.7\% of the athletes at Brown). In the spring, Brown directed its athletic department to cut its budget by 5-8\%. It decided to meet those budget cuts in part by demoting four varsity teams (men's water polo, men's golf, women's gymnastics, and women's volleyball) to club status. In 1992, the women's teams filed a Title IX lawsuit against Brown and successfully moved for a preliminary injunction to protect the affected teams (Cohen v. Brown University, 1992). The injunction was made permanent after a trial on the merits of the case. In ruling for the women's teams, the Cohen court had to interpret and apply Title IX's equal athletic participation opportunity regulation which provides:

Equal Opportunity. A recipient which operates or sponsors interscholastic, intercollegiate, club or intramural athletics shall provide equal athletic opportunity for members of both sexes. In determining whether equal opportunities are available the Director will consider, among other factors, whether the selection of sports and levels of competition effectively accommodate the interests and abilities of members of both sexes. \{34 C.F.R. 106.4 (c)(1)\}

The court looked to the 1979 Policy Interpretation for guidance. It describes equal opportunity for athletic participation in terms of the following 3-part test:

(1) Whether intercollegiate level participation opportunities for male and female students are provided in numbers substantially proportionate to their respective enrollments; or

(2) Where the members of one sex have been and are underrepresented among intercollegiate athletes, whether the institution can show a history and 
continuing practice of program expansion which is demonstrably responsive to the developing interest and abilities of the members of that sex; or

(3) Where the members of the one sex are underrepresented among intercollegiate athletes, and the institution cannot show a continuing practice of program expansion such as that cited above, whether it can be demonstrated that the interests and abilities of the members of that sex have been fully and effectively accommodated by the present program. \{(71418 (C.5.a.(1)-(3) Policy Interpretation); A Policy Interpretation: Title IX and Intercollegiate Athletics, 44 Fed. Reg. 71,413 et seq. (Dec. 18, 1979)\}

Brown University vigorously opposed application of the 3-part test by arguing that (1) prong 1 mandates an unconstitutional, affirmative action quota and (2) equality should be measured not by equal opportunity but by the perceived relative interests of the student body in athletics. The District Court of Rhode Island and two panels of the First Circuit Court of Appeals rejected both arguments.

The Cohen court recognized that athletics is unlike any other educational program, because it is sex segregated. Unlike the classroom, male and female students do not compete against each other for the same opportunities. Every school decides exactly how many opportunities it will provide to male and female students when it decides which sports to offer for each sex. There is no such thing as a "quota" in such a system, because as the Cohen court noted:

In this unique context, Title IX operates to ensure that the gender-segregated allocation of athletic opportunities does not disadvantage either gender. Rather than create a quota or preference, this unavoidably gender-conscious comparison merely provides for the allocation of athletics resources and participation opportunities between the sexes in a non-discriminatory manner. (Cohen v. Brown University, 1992)

The researchers contend, and the Brown University case decision later demonstrated, the only way to provide each student with an equal opportunity to participate in sports is to provide participation opportunities that mirror enrollment. If a public educational institution with an overall enrollment of 1000 of which $60 \%$ are females, only has enough money to provide 500 athletic participation opportunities, $60 \%$ of them (300) should be allocated to females and $40 \%$ of them (200) should be allocated to males. That way, each of the 400 males still has a 1 in 2 chance to play sports, as does each of the 600 females. This rationale is the basis for prong 1 , substantial proportionality. While it does not dictate how many opportunities a school must provide, it does require that they be allocated equitably. Otherwise, schools might recruit only enough women athletes to fill the slots they choose to create, rather than enough women to take advantage of a truly equitable program. "Substantial proportionality" has come to be regarded as the strongest test by which to measure equality in a sex-segregated program.

Brown University also argued that equity should not be based upon actual equal opportunity but upon equal satisfaction of the perceived relative interests of male and female students in athletics (Cohen v. Brown University, 1992). This view presumes that males are inherently more interested in sports, and thus more opportunities should be provided to satisfy those interests. To illustrate this theory of differential interest, we can picture a school that has 1,000 students, but this 
time evenly divided with 500 males and 500 females. It has enough money for only 500 athletic participation opportunities. If $75 \%$ of males (375) are "interested" in playing sports, while only $50 \%$ of females (250) are similarly interested, then opportunities should be provided in line with this ratio of interest or need. In this example, with 625 "interested" athletes, and only 500 slots available, only $80 \%$ of the participation opportunities could be filled. This would mean that 300 of the 375 "interested" males and 200 of the 250 "interested" females would be provided sport opportunities. This methodology, in effect, would reallocate 50 opportunities from females to males.

The Cohen court emphatically rejected use of the relative interests test in place of OCR's 3-part test (Cohen v. Brown University, 1992). As a legal matter, the court held that the 1979 Policy Interpretation was entitled to "considerable weight" as an agency's interpretation of its own regulation (Cohen v. Brown University, 1992, p. 988). Prong 3 of that test examines whether "the interests and abilities of the members of the under-represented sex have been fully and effectively accommodated." Both First Circuit panels in Cohen rejected the "relative interests" test because it would read the "full" out of the duty to fully and effectively accommodate the under-represented sex and would lock in current patterns of discrimination and men's historical advantages. The court emphasized that the test cannot withstand scrutiny on either legal or policy grounds because it disadvantages women and undermines the remedial purposes of Title IX by limiting required program expansion for the under-represented sex to the status quo of relative interests (Cohen v. Brown University, 1997).

The Cohen court further held to allow schools to provide fewer athletic participation opportunities to females based upon the premise that women are less interested in sports than men is, among other things, to ignore the fact that Title IX was enacted to remedy discrimination that results from stereotyped notions of women's interests and abilities. Interest and ability rarely develop in a vacuum; they evolve as a function of opportunity and experience. The Policy Interpretation recognizes that women's lower rate of participation in athletics reflects women's historical lack of opportunities to participate in sports (Cohen v. Brown University, 1997), and the Brown University decision became the case precedent that other Title IX challenges would be measured against.

Although not the original intent, the creation of opportunities that would develop interest and encourage women to participate in sports became a central purpose of Title IX. The growing theory among supporters was that more roster spots and scholarships would gradually increase demand among women for those roster spots and scholarships (Neal v. Bd. of Trustees Cal State Univ., 1999; Yuracko, 2002). Use of a relative interests test would instead "hinder and quite possibly reverse the steady increases in women's participation and interest in sports that have followed Title IX's enactment" (Neal, p. 769). In other words, it was argued that women are not inherently less interested in sports. Any disparity in "relative interests" is caused by longtime discrimination-discrimination that Congress enacted Title IX to eliminate. Thus, every court that has considered the relative interests test, including all the Cohen courts, has rejected it(Chalenor $v$. Univ. of North Dakota, 2002; Cohen v. Brown University 1992; 1997; Pederson v. LSU, 2000; Kelley v. Board of Trustees, 1994; Miami University Wrestling Club v. Miami University of Ohio, 2002; Neal, 1999). 


\section{5-A Return to Congress}

The early Title IX cases literally sent panic throughout the college ranks. As Colorado State University argued, if it had violated the 3-part test, then every college in America did also (Roberts v. Colorado State, 1993). Colleges and interest groups such as the AFCA lobbied Congress again to amend Title IX. Some sought to gain more leeway in prong 1. Others sought to exclude football entirely, as they had in 1970s. In May 1995, Congress held hearings and listened to the complaints of these interest groups again. (Cong. Rec. H4597, 1995).

Rep. Dennis Hastert (R-IL), a former high school wrestling coach, took the House floor on May 9, 1995, to ask his colleagues to amend Title IX. He blamed Title IX for the fact that four colleges in his state had either dropped or threatened to drop men's wrestling programs (Cong. Rec. H4597, 1995). Rep. Carolyn Mahoney (D-NY), on the other hand, retorted that schools were using Title IX as a convenient excuse for their own budget problems (Cong. Rec. E972, 1995). Still others argued that schools were blaming Title IX to galvanize the wrestling community and others to do their dirty work for them-convincing Congress to amend Title IX to relieve schools of their responsibilities (Cong. Rec. E972, 1995). Rep. Hastert attached an amendment into a U.S. Department of Labor/Health and Human Services appropriations bill (H.R. 2127, 1996) that directed DOE to reevaluate its 3-part test and to provide Congress with a clarification of that test.

Although the Senate removed that rider before passing the bill, OCR proceeded to prepare a detailed clarification of the 3-part test that it distributed for comment in September 1995. The final document was distributed in January 1996. This 1996 clarification reaffirms the 1979 Policy Interpretation's 3-part test and gives clear direction (with examples) on how it should be applied (Reynolds, 2003). In the end, after more heated debate, wrestlers and other interested parties were unable to convince Congress to amend Title IX or OCR to change its regulations.

\section{Back to the Courts: Suits by Dropped Men's Teams}

Having been granted no relief by either Congress or OCR, the wrestling community and others took their cause back to the courts. This time they sued the schools that eliminated the programs. Wrestlers filed lawsuits against Drake University, California State University at Bakersfield (CSB), the University of North Dakota (UND), and Miami University of Ohio. Men from other dropped sports filed suits against Illinois State University and the University of Illinois (Boulahanis v. Board of Regents, 1999; Chalenor v. University of North Dakota, 2000; Gonyo v. Drake University, 1995; Kelley v. Board of Trustees, 1994; Miami University Wrestling Club v. Miami University of Ohio, 2002; Neal, 1999). Those who represented the male athletes lost every one of these lawsuits primarily because they employed arguments that Congress, OCR, and prior courts had already rejected as contrary to the purposes and requirements of Title IX.

A recent, very public case involved Miami University of Ohio, which eliminated three men's sports in 1999, including wrestling. (Miami University Wrestling Club v. Miami University, 2001). In that situation, proponents of the wrestling program again argued that Miami's consideration of gender in deciding 
which sports to eliminate violated Title IX itself. To reach this position, the plaintiffs disregarded the 3-part test and instead argued that any consideration of gender in making a decision necessarily constituted illegal sex discrimination. The United States District Court for the Southern District of Ohio disagreed. It held that consideration of gender is not per se a violation of Title IX, because athletics teams themselves were separated by gender (Miami University Wrestling Club). It further held that the 1979 Policy Interpretation drew directly from the statute and was entitled to substantial deference. Accordingly, because males remained overrepresented in the athletic department even after the team cuts, they could not claim sex discrimination (Miami University Wrestling Club).

Lawyers also alleged that Title IX, as applied to the wrestlers, violated the Equal Protection Clause of the 14th Amendment to the U.S. Constitution because it allowed Miami to cut men's sports opportunities but not women's. The court again disagreed. Consideration of sex is constitutionally permissible when it is substantially related to an important governmental objective (Miami University Wrestling Club). Furthermore, the court noted that Title IX's objective of eliminating long-term discrimination against women in federally funded programs is unequivocally an important governmental objective. Finally, by cutting the three men's teams, Miami's reallocation of its athletic department resources in fact reduced that discrimination and thus was permissible (Miami University Wrestling Club).

Every court that has considered cases filed on behalf of male athletes challenging the elimination of their teams has rejected them. Courts universally recognize that colleges already overwhelmingly advantage males and provide them with more athletic opportunities than they provide females. Thus, even though individual wrestlers may lose the chance to wrestle, male students as a whole continue to receive the greater proportion of athletic opportunities. Thus, reductions, in themselves, do not constitute discrimination. With male opportunities still disproportionately high, it would appear that universities are choosing to favor some men's sports (such as football) over others (such as wrestling). Since male teams were not making any gains by filing their own lawsuits, they turned to the NWCA for assistance and in 2002 the NWCA filed their own lawsuit.

\section{The National Wrestling Coaches' Association Lawsuit}

Since lawsuits filed on behalf of collegiate teams had not been successful, proponents of wrestling turned to the NWCA for assistance. In 2002 the NWCA filed its own lawsuit.

The NWCA's complaint., aimed primarily at DOE, alleged that actions permitted by Title IX's 1979 Policy Interpretation and 1996 Clarification; (1) exceeded DOE's authority under the statute, (2) violated the equal protection principles in the due process clause of the Fifth Amendment to the U.S. Constitution, and (3) amended the Title IX regulation without complying with the Administrative Procedure Act (NWCA v. DOE, 2003; 2005). It also alleged that DOE improperly denied the NWCA's 1996 petition to amend or appeal the 1979 Policy Interpretation's 3-part test (NWCA).

In support of its complaint, the NWCA alleged that females inherently have less interest in sports and that colleges are eliminating or limiting the size of men's 
teams to reach substantial proportionality under prong 1 of the 3-part test because there are not enough women interested in sports to add new teams. The NWCA asked the court to declare the 1979 Policy Interpretation and 1996 Clarification null and void and to issue new guidelines that adopt the relative interests' tests rejected by all previous courts. DOE responded to the suit with a motion to dismiss for lack of jurisdiction under Federal Rules of Civil Procedure 12(b)(1), claiming that the NWCA did not have the standing to sue required by Article III of the Constitution because there was no connection between the relief they sought (invalidation of Title IX athletic policies) and their perceived harm (NWCA $v$. $D O E, 2003)$. In other words, it could not be established that DOE's Title IX policies caused colleges to drop wrestling programs. In fact, it was noted that during the years that Title IX was not applied to athletics because of the Grove City decision, colleges eliminated men's wrestling programs at a rate three times as great as they did after Title IX enforcement began. Thus, it could be argued that DOE's Title IX athletic policies had little or nothing to do with the elimination of those teams $(N W C A)$.

Moreover, even if the NWCA received the relief it requested, it would not redress the Wrestlers' claimed injuries. Different policies would not cause schools to reinstate wrestling programs or stop other schools with budget problems from eliminating them - or any other sport, for that matter. For example, the court noted that the University of Illinois' elimination of men's swimming had nothing to do with the Title IX policies but rather was because "the program was historically weak, swimming is not a widely offered athletic activity in the high schools, and it does not have a large spectator following" (Kelley v. Board of Trustees, 1994, p. 269). Only the schools that eliminated the teams-not DOE-could reinstate them, and those schools, the court noted, were not parties to the litigation. The supporters of wrestling, however, were well aware that suing the schools had not worked. Refocusing legal attention on the schools would no be a viable option.

After extensive briefing and oral argument - with the participation of amici on both sides - the District Court granted DOE's motion and dismissed the case (NWCA v. DOE 2003). This decision detailed the history of Title IX athletic policies and litigation and noted that every court that had addressed the propriety of Title IX's athletic policies had upheld them-both when used by women athletes to force schools to add women's sports and when challenged directly by male athletes (NWCA). Ultimately, the court found that the NWCA lacked standing because "this is not a case where "it can reasonably be supposed that the remedy, if granted, will inure to the benefit of those members of the association, actually injured"' (p. 129). Because the NWCA's appeals to the DC Circuit Court of Appeals and the U.S. Supreme Court also failed, Title IX's athletic policies and interpretations remained in place.

\section{A New Tactic: The Title IX Commission}

After once again failing with Congress and in the courts, wrestling advocates turned to the executive branch. After the inauguration of George W. Bush in 2001, they lobbied DOE and the new administration to change its Title IX athletics guidelines. DOE responded affirmatively and appointed members to a newly formed Commission on Opportunity in Athletics (Commission) to study the issue 
and to make recommendations about if and how the guidelines should be changed (Reynolds, 2003; Staurowsky, 2003).

Ten of the 15 commissioners came from the largest, most competitive NCAA Division I colleges with the largest and most expensive football programs. The Commission did not schedule witnesses from any new men's teams or any eliminated women's teams. The vast majority of invited witnesses were brought in to testify about the reduction in men's wrestling and gymnastics teams, and they singled out Title IX as the cause of these losses. No women who had lost their teams or who had been denied varsity status were invited to testify before the commission (Staurowsky, 2003; Yiamouyiannis, 2003).

In fact, in recent years schools have cut more women's gymnastics programs than men's teams-100 women's teams vs. 56 men's squads (General Accounting Office [GAO], 2001). In addition, while colleges had cut some men's teams, overall number of sports and participation opportunities for males had increased (Staurowsky, 2003). Many schools simply had reallocated resources from some men's sports such as wrestling to others, such as men's soccer (up 135 teams), baseball $(+85)$ and basketball $(+82 ; \mathrm{GAO})$.

Even more striking, the GAO Report and NCAA statistics showed that male students still received significantly more opportunities and resources, including $59 \%$ of participation opportunities (despite only $47 \%$ enrollment), $57 \%$ of athletic scholarships, $64 \%$ of athletic operating expenses, and $68 \%$ of recruiting expenses (GAO, 2001; NCAA, 2000). Thus, while women's participation opportunities have increased substantially under Title IX, they still lag behind both men's current and pre-1972 levels (GAO). Disparities at the high school level remain even greater. The Title IX Commission report cited annual National Federation of State High School Athletic Associations participation surveys showing that more than 1.1 million more male than female high school students receive athletic opportunities. In sum, the facts contained in the report showed that at the high school and college levels, females still receive far fewer sport participation opportunities than males, and overall sport opportunities for males continue to increase.

The Commission eventually issued a report that made sweeping recommendations for changes in the Title IX guidelines-arguably, changes that directly conflicted with the statute itself and legislative history. Commissioners Donna deVarona and Julie Foudy issued a minority report that opposed many of the recommendations and laid out what they believed to be the underlying facts that demonstrated men continue to receive preferential treatment in athletics (deVarona, 2003; Foudy, 2003). Both reports generated heated debates, but polls showed that Americans recognized the importance of Title IX for promoting equal opportunity and supported its vigorous enforcement (deVarona; Foudy). Moreover, groups such as the National Coalition on Women and Girls in Education and the American Bar Association issued a commentary noting that the Commission's recommendations conflicted with the law, its legislative history, and its purpose (National Coalition for Women and Girls in Education, 2002) In the end, DOE took no substantive action to change any of Title IX's athletic guidelines because DOE Secretary Rod Paige stated he would only accept unanimous recommendations. Foudy and DeVarona's minority opinion carried substantial weight even though they were outnumbered. DOE subsequently issued a July 2003 letter urging more education and technical assistance for schools and more Title IX 
enforcement but not any backward steps that would harm the letter and spirit of the law (Reynolds, 2003).

\section{Part III: The Economic Reality of Intercollegiate Athletics and Recommendations for Change}

The authors contend that the driving force behind the loss of many men's sport programs over the past 20 years has been a shift in institutional priorities related to achieving excellence in football and basketball coupled with economic factors involving the arms race, not the drive for equality. In a 2007 article, the sports editor for the Chronicle of Higher Education predicted that, "as financial pressures mount, more athletic departments will eliminate sports" (Wolverton, 2007, p. A28). In addition, Cheslock (2007) encouraged future research that would examine reductions in men's sports teams in relationship to the arms race in athletic spending at the FBS level. We contend that controlling costs in intercollegiate athletics, not changing Title IX guidelines, is they key to ensuring that sports such as wrestling, men's and women's swimming, men's and women's track and field, and many other endangered sports will continue to exist on college and university campuses.

While several male sports programs have been dropped, comparative spending on intercollegiate athletic programs has reached almost unsustainable growth with overall athletic budgets increasing by 20\% between 2001 and 2003 (Orszag \& Orszag, 2005). During this same time period, institutional spending increased only 5\% (Orszag \& Orszag). Spending in intercollegiate athletics escalates each year as institutions strive to attain greater and greater success in a few select sports. Over $\$ 4.2$ billion was spent in 2005-06 to support the operations of the FBS athletics programs (Lawrence \& Li, 2007). While increased spending in the sports of football and men's basketball is often highlighted most frequently, spending in other areas is also escalating.

The Knight Commission, an intercollegiate athletics watchdog group, has noted that "[a] frantic, money-oriented modus operandi that defies responsibility dominates the structure of big-time football and basketball" (Knight Commission, 2007, I[20). The most recent NCAA data indicated that in 2006, only 19 of the 119 FBS member institutions reported revenues exceeding expenditures if university contributions are excluded from the calculation (Fulks, 2008). It is interesting to note that no relationship has been found between operational spending on football and basketball and increases in winning, operating net revenue, academic quality, or alumni giving (Litan, Orszag, \& Orszag, 2003). In fact, there is evidence to suggest that there is a net zero impact on revenue when examining football and basketball expenditures in the FBS, so $\$ 1$ of football or men's basketball expenditure results only in an additional $\$ 1$ of operating revenue (Litan, et al.).

By examining per athlete expenses related to gender specific costs within athletic departments, excess becomes apparent. During 2005-06, the average expense in the FBS was $\$ 58,025$ per male student-athlete and $\$ 32,308$ per female student-athlete-an increase of $\$ 9,451$ and $\$ 3,207$ from the previous year (Lawrence \& Li, 2007). It has also been reported that at some FBS institutions, the cost of supporting a football player exceeds $\$ 100,000$ per athlete (Knight 
Commission, 2007). With respect to football, $41.6 \%$ of FBS expenditures allocated to a specific sport go to football-26.2\% and $29.0 \%$ for FCS and Division II with football (Cheslock, 2007).

\section{Misplaced Financial Priorities}

A recent and salient argument that identifies economic decisions, rather than gender equity legislation, as the primary reason for the demise of many male sports, is the recent dropping of six men's sports at Rutgers University in 2006 (Coalition to Save our Sports, 2008). Rutgers can be viewed as a microcosm of the economic realities and high stakes at some major NCAA Division I institutions, specifically in the sports of football and men's basketball.

Rutgers made a decision to substantially increase their financial support for football in the late 1990s to pursue the intangibles that a winning football program may or may not bring to a university (Associated Press, 2006b; Sack \& Staurowsky, 1998; Suggs, 2003). Rutgers hired University of Miami assistant coach Greg Schiano to resurrect its football program in 1999. While the program struggled in the early years of Schiano's tenure, the money needed to make the program better flowed in. The program began to win games and become more competitive, culminating in a postseason bowl appearance in 2005. Not wanting to stem the success of the football program, even with millions in impending state budget cuts affecting the entire university, the athletic department decided to drop six men's sports in 2006 (heavyweight crew, lightweight crew, fencing, swimming and diving, tennis), as well as women's fencing to help meet both the financial bottom line and gender equity requirements (Rimbach \& Alex, 2006). Rutgers officials contended the sports had to be dropped to meet Title IX requirements and save $\$ 2$ million in the face of almost $\$ 55$ million in major state budget cuts (Associated Press, 2006a). However, the athletic department simultaneously detailed major increases in expenditures for its football program in the form of facility improvements and coaches' salaries-ironically totaling about \$2 million (Associated Press, 2006b).

Rutgers' athletic spending doubled over 7 years, from $\$ 23.5$ million in 1998-99 to almost \$41 million in 2005-06 (Rimbach \& Alex, 2006). Yet the money was not allocated evenly across sports, with much of the increase going to football and men's basketball. Football spending at Rutgers has grown from $\$ 6.3$ million, or $26.8 \%$ of the budget, in $1998-99$, to $\$ 13$ million, or $31.7 \%$, in $2005-06$ (Associated Press, 2006b)

According to the Equity in Athletics Disclosure report for the 2004-05 year, Rutgers' football program broke even with $\$ 10.7$ million in revenue (Coalition to Save our Sports, 2008). However, that included nearly $\$ 3$ million in university support and student fees. Some other examples of increases in football spending at Rutgers included incentives for Schiano, who was earning more than \$1 million per year. The university spent millions on new football facilities, including $\$ 12.5$ million for an expansion and renovation of the team's training center and $\$ 175,000$ to house the team in a local hotel for six home games. Rutgers received \$1.25 million for its 2005 Insight Bowl game, its first bowl appearance in decades. However, after paying for everyone to go to the game-including players, coaching 
staff, additional university officials and family members - the university finished $\$ 19,000$ in the red (Associated Press, 2006a).

Rutgers athletic director E. Robert Mulcahy sounds a familiar refrain when he argues that the team's success should not be measured just in financial terms, but also by the attention it draws to the university (Associated Press, 2006b; Suggs, 2003). Many who support increased investment in football and men's basketball programs at the expense of nonrevenue sports programs will point to several potential intangibles, such as greater exposure for the university, increased athletic and academic donations, increased quality of applicants, and greater marketing and recruiting potential (Suggs). This is often called the "Front Porch Theory," meaning that athletics can be, and possibly is, the main window through which the general public views the institution (Suggs). Therefore if the front porch is untidy, the rest of the institution will suffer in the aforementioned areas (Suggs). Increased expenditures in the sports of football and men's basketball are intended to "repair the porch" but they do not necessarily correlate with greater winning percentages or other intangible benefits (Orszag \& Orszag, 2005; Sack \& Staurowsky, 1998). Still, Rutgers is not the only athletic program to drop sports, male and female, in the name of Title IX while pumping more dollars into football and men's basketball programs that are either losing money or breaking even.

\section{The Facility Arms Race}

Athletic facility spending has significantly contributed to the escalating costs of operating a FBS intercollegiate athletics department. Between 1994 and 2001, capital expenditures (e.g., new facility construction, renovation, and capital equipment acquisitions) increased 250\% (Knight Commission, 2007). Examples of facility expenditures that serve to illustrate this point include one institution that dropped a men's sport program also spent $\$ 300,000$ on lights for their football practice field and then never used the field for practice during the coach's tenure (Lopiano, 2001). Another university dropped its men's swimming and diving program for financial reasons and then renovated the outdoor track and indoor track, built a baseball complex (with underground soil-heating elements), added a row of skyboxes to the football stadium, and installed artificial turf in the football stadium (Lopiano). In summary, some of the same colleges that have significantly increased their athletics budgets and increased capital expenditures on facility renovation and expansions have chosen to also decrease sport opportunities for male athletes.

According to NCAA statistics, even though many male teams have been eliminated since the inception of Title IX, women still receive fewer sport opportunities based upon enrollment figures at public institutions. Carpenter and Acosta state that,

Institutions who failed to meet any of the three prongs of the participation test all too often decided to manipulate numbers rather than expand opportunities ... the manipulation of numbers typically included terminating the men's "minor" sport teams (e.g., wrestling, gymnastics, and swimming) rather than, for example, curbing the excesses of football. (2005, p. 185) 


\section{Reducing Scholarship Expenses}

Between the rising cost of tuition and unnecessarily large men's football scholarship limits, institutions are spending more than ever on athletic scholarships for their student-athletes. College tuition increased 35\% between 2001 and 2006 (after adjusting for inflation), which athletic department budgets must absorb when awarding athletics aid (College Board, 2006). The NCAA permits 85 full football scholarships in The FBS and 63 full football scholarships in the Football Championship Subdivision (FCS; formerly Division IAA), but only, 9.9 equivalency scholarships in wrestling (one scholarship can be split among multiple players; NCAA, 2007d).

In 2002-03 FBS male student-athletes received an average of \$2.65 million in scholarship dollars per institution, while female student-athletes received $\$ 1.96$ million on average (Fulks, 2005). At the FCS level, \$1.3 million was spent for men's athletic scholarships and just over $\$ 1$ million was spent on women (Fulks). The large number of football scholarships permitted in the FBS costs institutions thousands of extra dollars each year that could be invested in other sport programs. It is difficult to imagine that football success would diminish if the scholarship limit were reduced by 20 and those 20 new walk-on student athletes became tuition-paying students, providing revenue to the university (even though some costs are still associated with carrying walk-on student-athletes).

Hypothetically, the redistribution of scholarship money might occur like this: Public Institution A is facing a financial shortfall next year and has chosen to eliminate 20 football scholarships to help balance the budget. Currently, the institution has 115 FBS football players, 85 of whom are on full scholarships. The average tuition, fees, room, and board in 2006-07 for an in-state student was $\$ 12,796$ (College Board, 2006). By eliminating 20 full scholarships, the athletic department (if all of the players were an in-state student, which is extremely rare) immediately would save $\$ 255,920$ per year. Assuming the total roster size remained unchanged, the university would net that same amount in tuition income. The savings would support the $100 \%$ of most wrestling operating budgets at Division I institutions considering the relative small wrestling budgets mentioned earlier (U.S. Department of Education Office of Postsecondary Education, 2007).

\section{Reducing Recruiting Expenses}

Excessive recruiting costs are rampant at the FBS level. In 2002-03, average recruiting expenditures were $\$ 378,000$ for men's teams and $\$ 163,030$ for women's programs (Fulks, 2005). During the same year, FCS schools spent an average of $\$ 104,000$ on recruiting for men and $\$ 58,000$ for women (Fulks). Among the top spending FBS institutions, four schools reported men's recruiting expenditures exceeding $\$ 1$ million and 50 institutions spent over $\$ 500,000$ recruiting male student-athlete (Lawrence \& Li, 2007). No institution reported spending more than $\$ 500,000$ to recruit female student athletes (Lawrence \& Li).

The large difference between FBS and FCS expenditures brings up two questions: "Why are FBS institutions spending over $31 / 2$ times more than FCS to recruit male student-athletes?" and "Why are FBS institutions spending $11 / 2$ times more than FCS institutions to recruit female student-athletes?" Both divisions seem to have no problem filling rosters with participants, so wouldn't fis- 
cally sound decision-making lean toward cutting recruiting costs? If the average FBS institution reduced its recruiting spending by $10 \%$ across the board, the remaining money could support the entire scholarship limit for a wrestling team, a men's track and field team, or a men's swimming team.

\section{Controlling Coaches Salaries}

FBS college football coaches are making more money than ever. In 2006, of the 119 FBS head football coaches, at least 42 were earning \$1 million or more (Upton $\&$ Wieberg, 2006). The percentage of the athletic budget devoted to football salaries also is increasing, accounting for more than $10 \%$ of the total athletics operating budget at one major FBS institution (Estes, 2007).

Controlling coaches' salaries has been both an emotional and legal issue. Every attempt to regulate salaries by the NCAA has been met with stiff resistance and legal battles. Currently, without an antitrust exemption, there is little that can be done in stemming ever growing salaries unless institutions do it themselves. To date institutions seem unwilling to make such decisions unilaterally. However, any collusion or restraint of trade will likely result in a costly lawsuit. Consequently some institutions are paying their head football coach far more than the entire budget of a wrestling team. If greater discipline were exercised in the area of coaches' salaries, participation opportunities in minor sports could be preserved or increased.

\section{Additional Areas of Savings}

Apart from salaries, scholarships, and recruiting, a number of other, smaller lineitem expenses can be identified. While they may not be significant individually, when added up they produce considerable savings - savings that could be reallocated to increased participation opportunities.

Academic support for student-athletes is a source of potential overspending at some institutions. One major FBS institution spent $\$ 19.5$ million on their academic support center for student-athletes and has 15 staff members to meet the academic needs of student-athletes (Louisiana State University, 2007). These indirect costs are spread among walk-on and scholarship student-athletes and can add up to significant amounts of money.

This need could be met in other, less expensive ways. Most institutions have well developed academic support services for all students on-campus that could serve (with some adjustments) many of the needs of student-athletes. Thus, the value of separate and special academic support centers for student-athletes should be measured in relationship to the advantages of investing this same money in the retention or expansion of participation opportunities.

Another area where costs can be cut is related to the football tradition of housing athletes at local hotels or motels before home games. One institution sequestered its football team at a local hotel before their six home games at a cost of $\$ 175,000$ while, at the same time, cutting its tennis team. The entire tennis budget was less than the cost of the football team's hotel rooms (Rimbach \& Alex, 2006). Another team spent $\$ 86,000$ just on snack food at a local hotel during preseason football training camp (Lopiano, 2001). 
This is not an exhaustive list of line-item expenditures in college athletics and the areas discussed do not represent a large portion of the overall athletics budget. Neither does a wrestling program. Thus, it is the contention of the authors that all expenditures should be examined before a decision to cut a sport to ensure that no expenses could be reduced for purposes of saving a sport team.

\section{NCAA Revenue Distribution Model Adjustment}

According to the NCAA's revenue distribution model, the amount of money that is paid to conferences during the Division I men's basketball tournament is enormous, and it increasing each year. "The NCAA's revenue distribution formula for the new CBS contract values each win in the Division I men's basketball tournament at $\$ 780,000$. Thus, the stakes for a foul shot to win a game in the tournament will exceed three-quarters of a million dollars" ("Knight Commission," 2007, I29). The total amount of money available to share among teams in the Division I basketball tournament has risen from \$75 million in 2001-02 to almost \$123 million in 2005-06 (NCAA, 2007c). The big winners in 2006-07, taking home the most money for their members, were the Big East $(\$ 14,856,576)$, Big 12 $(\$ 14,325,984)$, Big Ten and Atlantic Coast $(\$ 14,149,129 ;$ NCAA, 2007c). On the other end of the spectrum are the eight conferences receiving the minimum payout of $\$ 1,061,184$ (NCAA, 2007c).

Regarding NCAA revenue distribution, expenses, and allocations, as indicated in Tables 1 and 2, about a third of the Division I allocation (34\%) is disbursed through the basketball fund, about a third (34\%) through broad-based distribution, $15 \%$ to student programs, and $13 \%$ for general programs and services. The basketball fund monies are paid to Division I conferences based on their performance in the men's basketball tournament over a six-year period. The payments are divided into units, with one unit awarded to each institution that participates in each game, except for the championship (NCAA, 2007b). "In 2006-07, each basketball unit will be approximately $\$ 177,000(\times 6)$ " (NCAA, 2007b, p. 5b). Starting in 1990-91, payments to NCAA member institutions for participation in NCAA championships other than men's basketball were eliminated. Instead, those monies were funneled into the NCAA's general budget for general distribution (NCAA, 2007a). In short, on average about $\$ 1$ million is now paid out for participating in each game of the men's basketball tournament $(\$ 177,000 \times$ 6 ). However, there is no NCAA institutional/conference payout for participation in any other NCAA men's or women's championship.

Division I payouts are large for winning in men's basketball (over \$132 million in 2006-07) and still handsome for not winning (\$1 million for losing in the first round) - but there is no NCAA payout for winning competitions in any other NCAA men's or women's championship bracket. A financial incentive could motivate some schools to invest more equitably in their sport programs or even retain minor men's sports and women's programs if they have a chance for financial reward for performance.

Other financial incentives for offering a large number of programs are also lacking. Only $11 \%$ (\$44.2 million) of the Division I allocation is distributed on team sponsorship. This means that a school would receive only $\$ 22,000$ per team offered above the minimum. If the purpose of higher education is, at least in part, 
Table 1 NCAA Revenues and Expenses (2006-2007)

\begin{tabular}{lcc}
\hline Source & $\begin{array}{c}\text { Amount in } \\
\text { \$millions }\end{array}$ & $\begin{array}{c}\text { Percent } \\
\text { of total }\end{array}$ \\
\hline Revenue & & \\
\hline $\begin{array}{l}\text { Television and marketing rights } \\
\quad \text { primarily men's basketball) }\end{array}$ & 508.3 & 90.1 \\
Total championships revenue & 44.9 & - \\
Investments, fees and services & 9.8 & - \\
Membership Dues & 1.0 & 100.0 \\
Total revenues & 564.0 & 69.1 \\
\hline Expenses & & 4.4 \\
\hline Division I allocation & 389.8 & 3.2 \\
Division II allocation & 24.7 & 16.9 \\
Division III allocation & 17.9 & - \\
NCAA programs and services & 95.2 & - \\
$\quad$ student-athlete welfare and youth programs & 22.6 & 4.3 \\
$\quad$ membership programs and services & 72.6 & 2.4 \\
Administrative services & 22.8 & 100.0 \\
$\quad$ (general and administrative expenses/support) & & \\
Contingencies and reserves & 13.6 & \\
Total expenses & 564.0 & \\
\hline
\end{tabular}

\section{Table 2 NCAA Division I Breakdown of Expenses/Allocations}

\begin{tabular}{lc}
\hline Allocation & Amount in \$millions \\
\hline Basketball fund & 132.6 \\
Broad-based distribution & - \\
$\quad$ number of varsity sports sponsored & 44.2 \\
$\quad$ number of athletics grants in aid & 88.4 \\
Student athlete opportunity fund & 27.7 \\
Academic enhancement fund & 19.8 \\
Special assistance fund for student-athletes & 12.3 \\
Conference grants & 6.8 \\
Budget allocations for programs and services & b \\
Total & $55.0+$ \\
\hline
\end{tabular}

to provide participation opportunities to students, the authors suggest revision of the NCAA budget to earmark a significantly greater portion of revenues to colleges and universities based on the number of sport teams offered. Perhaps too, a greater incentive should be provided for championship participation in sports other than basketball. 


\section{Women's Wrestling}

Men's wrestling advocates continue to overlook the most promising answer to their concerns-women's wrestling. At large institutions, wrestling budgets are typically one of the smaller line items. At the NCAA Division I level, wrestling budgets range from close to $\$ 100,000-200,000$ per year for the less competitive teams to over $\$ 900,000$ for the perennial nationally competitive teams, such as the University of Iowa (University of Iowa, 2007). By contrast, the University of Iowa football budget in 2007 alone was close to 16 million dollars (Fresno State University, 2006; University of Iowa, 2007). Thus, rather than cut men's wrestling for limited savings, wrestlers could encourage schools to add women's wrestling opportunities. The cost of adding women's teams and opportunities to already existing men's wrestling teams is relatively small compared with football expenditures. Moreover, if men's teams are balanced with women's teams, they will less likely be considered for elimination when schools face budget cuts. Furthermore, the intent and spirit of Title IX is to increase opportunities for women (not to decrease opportunities for men). Thus, choosing to add women's wrestling would be consistent with not only the letter of the law, but also the spirit and intent of this legislation.

Some successful state and club programs suggest that girls wresting would be successful-if opportunities for participation are provided. Three state high school athletic association's (Texas, Hawaii, and Washington) already sanction girls' wrestling with separate state tournaments, and California recognizes girls' wrestling as an exhibition sport (Smith, 2004). As of 2004, nearly 3,800 girls were competing on girls' teams through their schools and the California Women's Wrestling Association (Smith). The United States Girls' Wrestling Association began a high school girls' national tournament in 1997, and it now sponsors state and regional tournaments throughout the nation. Entries have been increasing each year (Smith).

Women's wrestling has flourished at the international level for decades, is now a medal sport in the Olympics, and was showcased at the 2008 Beijing Olympics. In Canada, nearly every college with a men's wrestling team has a sister women's wrestling team (Robinson, 2008). Some American institutions such as Menlo College, Missouri Valley, Cumberland, and MacMurray have chosen to add women's wrestling teams and have successfully recruited large numbers of women to attend their schools to participate in the sport (Varsity Women's Wrestling Teams, 2008). Other schools have allowed women to participate on their men's teams as a way to train for women's open competition (Smith). Indeed, this was the training ground for such U.S. National team wrestlers as Patricia Miranda and Sara McCann (Robinson).

USA Wrestling is responsible for developing national teams and Olympic athletes for both men and women (The Mat.com, 2008). The NWCA could potentially double its membership if it encouraged the addition of women's teams. It is time for such organizations to stop spending millions of dollars challenging Title IX and to turn those resources and energy toward developing opportunities in the sport for women. Together, men's and women's wrestling programs could better fight sport elimination. Furthermore, they could align with other women's and men's sport teams to jointly challenge existing resource allocations to football and 
basketball programs. If successful, the change in strategy could serve to benefit current and future wrestlers for many years to come.

\section{NCAA Certification and Sports Sponsorship}

The NCAA athletics certification program was adopted at the 1993 NCAA Convention and was designed to hold Division I colleges accountable for athletics operations. During the first cycle, through a self-study and peer review process, athletics operations were reviewed in the following areas: (a) governance and rules compliance, (b) academic integrity, (c) fiscal integrity and (d) equity, welfare and sportsmanship. The program is designed to help colleges identify problems areas and to correct them (Division I Certification Program, 2008). As part of the certification process, each institution is required to complete a gender equity plan and is evaluated on aspects of gender equity within the institution (Division I Certification Program). For the second cycle, the fiscal operations component has been eliminated (Division I Certification Program). To promote full disclosure on budget excesses, the authors contend that the fiscal component should be reinstated.

Regarding NCAA sport sponsorship, according to NCAA Bylaw 20.9 (2008), Division I FBS schools must sponsor at least 16 sports (of which at least 6 must be for men and at least 8 for women) and Division I FCS schools must sponsor at least 14 sports (of which at least 6 must be for men and at least 7 for women). These floor-level requirements have essentially become ceilings for some institutions, inasmuch as some colleges have decided trim sports to the bare minimum required by NCAA legislation. The authors suggest that to ensure the continuation of broad-based programs, the NCAA membership should consider amending NCAA legislation to gradually increase the minimum number of sports required for divisional membership. Such action would be consistent with the Division I Philosophy Statement which indicates that the offering of extensive opportunities for participation in varsity sports is a priority (NCAA, 2008, Bylaw 20.9).

\section{Presidential Philosophical Change}

At the core of any institution is the philosophy of the president. In the case of athletics, that philosophy dictates decisions related to sport sponsorship, Title IX compliance, and spending of athletics dollars. At the presidential level, priorities related to intercollegiate athletics and its place within higher education need to be reexamined and balanced. University presidents need to take greater responsibility in acknowledging causes for the current situation and to spearhead future efforts for change.

Former University of Michigan President James Duderstadt identifies the root of the problem related to the wrestling argument. Duderstadt (2003) places blame for the cutting of men's (and women's) sport teams on the poor choices made by athletics leaders in adopting rule changes in football rather than Title IX or women:

When faced with limited resources, sometimes universities perceive, mistakenly ... that their only option is to free up opportunities for women by 
reducing opportunities for men. . . . It is clearly wrong to place the burden of eliminating men's sports programs on the back of the women's programs. Rather the burden should be placed squarely where it belongs: on the back of our football programs. After all, it is the absurd practice of tolerating in football a men's athletics program several times as large as any other sport that makes it so hard to achieve gender equity. When the football coaches pushed through rule changes to allow unlimited substitution in the 1960s and ballooned the size of their sport to involve squad sizes of over one hundred players and dozens of coaches per team, they, in effect, sentenced a number of men's sport programs to extinction. The real question is whether we should continue to accept a football paradigm with so many players, coaches, and expenses at the expense of other sports programs (men's and women's). (Duderstadt, p. 212)

Duderstadt (2003) primarily blames insufficient presidential leadership for allowing football and basketball to be engulfed by the entertainment industry and extensively commercialized and professionalized leading to the corruption of college sports. Furthermore, he states that "[g]ender equity is clearly the right goal for higher education" (p. 213). He suggests that university presidents need to step up to the plate and be willing to face the pressure to reform college sports (Duderstadt). He also asks whether university presidents should continue to allow football excess to negatively affect other men's and women's sport teams (Duderstadt).

The Knight Commission reinforces this position and believes college presidents and athletics directors need to reexamine priorities related to intercollegiate athletics and its place within higher education and to work with the athletics community to change course.

The plain truth is that one clear and convincing message needs to be sent to every member of the academic community: What is needed today is not more rules from above, but instead a concerted grassroots effort by the broader academic community-in concert with trustees, administrators and faculty- to restore the balance of athletics and academics on campus (Knight Commission, 2007, Ф12).

Instead of continuing to compete in the so-called intercollegiate athletic arms race and increasing football and basketball budgets at the expense of other sport opportunities, presidents need to set the tone from the top and refocus on the value of sport for students versus the entertainment value of sport for fans. Athletics directors and coaches should also be held responsible for providing leadership in this direction.

\section{Capping Men's Sports}

Schools that implement participation limits for men's sports may find that significant benefits result. In general, capping occurs by eliminating most walk-on positions, which usually does not impact the competitiveness of the team (Women's Sports Foundation, 2000). The cost savings from eliminating extra participants then allow those dollars to be redirected toward underfunded men's sports and women's sports. For institutions seeking to comply with Title IX and considering 
eliminating a men's sport to meet the requirements of proportionality, capping men's sport teams may be one option. Institutions also will find that reducing walk-on players will achieve the same result as dropping entire teams, but without eliminating a sport opportunity. Rosters of men's sport teams have grown, resulting in increased overall participation opportunities for male student-athletes even though sport team offerings have essentially stayed the same over time (Cheslock, 2007). FBS institutions have eliminated more sport teams than FCS and Division I without football (formerly IAAA) combined, yet they also have the largest number of student-athletes participating per institution (Cheslock, 2007; NCAA, 2007). Thus, capping sport teams in FBS could lessen the need to drop teams as a means to achieve compliance with Title IX.

\section{State Legislation}

Another area that should be explored is state gender equity legislation. More than 20 states have enacted some sort of gender equity legislation (Women's Sports Foundation, 2000). There have been a variety of approaches to helping institutions become more equitable. In Florida, institutions are held accountable for following their own gender equity plan; institutions not in compliance with Title IX cannot compete for state grants and may have state funding withheld (Curtis \& Grant, 2007). In Louisiana, institutions are provided up to 50 tuition waivers for female student-athletes per year; in Washington, specific funding has been set aside to build women's sports facilities; and in New Mexico, money is allocated to state institutions to improve gender equity (Curtis \& Grant; Women's Sports Foundation). These examples of state legislative actions are an excellent way to help institutions seek out new revenue without jeopardizing existing athletic teams.

\section{Economic Change and the Tax Exempt Status of the NCAA}

Another issue often raised is whether the enterprise of intercollegiate athletics, specifically at the FBS level, contributes to the educational mission of the institution (Splitt, 2004). Many outside reform groups, such as The Drake Group (TDG), are pursuing a review of the NCAA's tax exempt status as a means to encourage academic integrity, and to contain costs. Congress is looking at the issue as well: In November 2006, Rep. Bill Thomas, former chair of the House Ways and Means Committee, sent a 16-page letter to NCAA President Myles Brand (Thomas, 2006). The letter asked pointed questions about whether the NCAA deserves its tax exemption and whether its mission supports nonprofit higher education (Thomas). Opponents would argue that less money means less opportunity, but supporters counter that forcing the enterprise to live within its means can enhance greater opportunity for all by curbing frivolous expenses and encouraging more reasonable spending for all sports, not just for a select few.

Big 10 Conference Commissioner Jim Delany reluctantly admits that removing the tax exempt status of Division I institutions might force institutions to channel funding into what is needed, rather than continue the excesses that contribute little to the educational mission of the university (Splitt, 2004). In a CNN/SI interview, Delany alluded to the fact that controlling costs might increase the funding levels for certain sports. Specifically, he stated, "We would be foolish to try and 
defend some of the things we do. There are things that we do that are excessive, things like hotels and charter travel and the like. . . . [W] might even be more efficient if we were taxed. It may end up helping us" (Munson, 2006, p. 2). If institutions are held more accountable for the dollars they are spending and are taxed for excessive expenditures, perhaps athletic dollars would be managed better and allocated more equitably. Such action would serve to provide greater transparency and accountability.

\section{Conclusion}

After more than 30 years, supporters of wrestling are still focused on the wrong foes: women and Title IX. As discussed throughout this article, the root causes of the loss of college wrestling teams arguably can be found in out-of-control and unfair economics in big-time college athletic programs-specifically, the reallocation of money from some men's sports (such as wrestling) to other men's sports (such as football, basketball, and even baseball). Overall, men still receive preferential treatment in college athletic programs, but within the men's programs, some men's sports clearly receive better treatment than others. In this kind of athletic landscape, it is difficult to argue that the problem lies primarily with Title IX.

The authors conclude that legal and legislative actions challenging Title IX have been exhausted and are like to remain ineffectual in preserving opportunities for males in sports like wrestling. Therefore, it is time for a new game plan-one that will focus on reducing costs and managing the intercollegiate athletics enterprise more appropriately. The examples provided show that resources are available to fully fund sports such as wrestling through a reallocation of existing athletics dollars. Wrestling advocates are therefore advised to work collaboratively with Title IX advocates as well as proponents of women's sport teams and other men's minor sport programs so that greater attention is placed on providing broad-based sport participation opportunities for both men and women.

\section{References}

20.U.S.C. $\$ 1681$ (a) (7-9).

34 C.F.R. 106.4 (a).

34 C.F.R. 106.4 (c) (1).

120 Cong. Rec. 15,322-15,323, (1974).

120 Cong. Rec. 15,340, (1974) (Tower Amendment).

71418 (C.5.a.(1)-(3) (1979) (Policy Interpretation).

Policy Interpretation: Title IX and Intercollegiate Athletics, 44 Fed. Reg. 71,413 et seq. (Dec. 18, 1979).

Associated Press. (2006a, July 14). Budget casualty: Rutgers forced to cut six sports. Retrieved October 8, 2007, from http://sports.espn.go.com/ncaa/news/ story?id=2519938.

Associated Press. (2006b, November 18). Rutgers invests in football but cuts other sports. Retrieved November 2, 2007, from http://sports.espn.go.com/ncf/news/ story? id=2667334.

Bell v. Dougherty, 456 U.S. 986 (1982).

Bennett v. West Texas State University, 799 F.2d 155 (5 $5^{\text {th }}$ Cir. 1986). 
Benson, D. (2007, October 8). Taking a hit: While women's programs flourished under Title IX, men's athletics suffered. Fort Wayne News Sentinel. Retrieved October 8, 2007, from http://fwnextweb1.fortwayne.com/ns/projects/title9/title910.php.

Boulahanis v. Board of Regents of Illinois State University, 198 F.3d 633 (7th Cir. 1999).

Brady, E. (2007, April 19). James Madison's hard cuts spur Title IX debate. USA Today. Retrieved on November 2, 2008 from http://www.usatoday.com/sports/college/ other/2007-04-19-title-ix-jmu-cover_N.htm.

Carpenter, L.J., \& Acosta, V. (2005). Title IX. Champaign, IL: Human Kinetics.

Chalenor v. University of North Dakota, 142 F.Supp. 1154 (D.N.D. 2000), aff'd, 292 F.3d 1042 ( $8^{\text {th }}$ Cir. 2002).

Cheslock, J. (2007). Who's playing college sports? East Meadow, NY: Women's Sports Foundation.

Coalition to Save our Sports. (2008, August 27). Revisited: Coalition to save our sports responds to Rutgers media statement. Piscataway, NJ: Author.

Cohen v. Brown University, 809 F.Supp. 978 (D.R.I. 1992), aff'd, 991 F.2d 888 ( $1^{\text {st }}$ Cir. 1993, remanded, 879 F.Supp. 185 (D.R.I. 1995), aff'd in part, 191 F.3d 155 ( $1^{\text {st }}$ Cir. 1996), cert. denied, 520 U.S. 1186 (1997).

College Board. (2006, October 24). Tuition increases continue to slow at public colleges according to College Board's 2006 reports on college pricing and financial aid. Retrieved October 4, 2007, from http://www.collegeboard.com/press/releases/150634. html

College Sports Council v. Department of Education, 357 F.Supp.2d 311 (D.D.C. 2006), aff'd in part, 465 F.3d 20 (D.C. Cir. 2006), reh'g denied, (2007), cert. denied, _ U.S. , 2007 WL 707330 (2007).

College Sports Council v. General Accounting Office, Case No. 03-cv-1911 (D.D.C. 2003).

College Sports Council v. Paige, Case No. 03-cv-1740 (D.D.C. 2003).

Cook v. Colgate University, 802 F.Supp. 787 (N.D. N.Y. 1992).

Congressional Record H4597, (1995).

Congressional Record E972, (1995).

Crowley, J. (2006). In the arena: The NCAA's first century. Indianapolis, IN: The NCAA.

Curtis, M., \& Grant, C. (2007). State legislation. Retrieved September 25, 2007, from http://bailiwick.lib.uiowa.edu/ge/stateRE.html.

Department of Education v. Seattle University, 456 U.S. 986 (1982).

de Varona, D. (2003, February 20). Text of letter to the Title IX commission. USA Today. Retrieved on August 28, 2008 from http://www.usatoday.com/sports/college/2003-02-24-titleix-devarona-letter_x.htm.

Division I Certification Program. (2008). Retrieved August 29, 2008 from http://www1. ncaa.org/membership/membership_svcs/athletics_certification/index.

Dougherty County School System v. Harris, 622 F.2d 735 (5 $5^{\text {th }}$ Cir. 1980).

Duderstadt, J. (2003). Intercollegiate athletics and the American university: A president's perspective. Ann Arbor, MI: The University of Michigan Press.

Equity in Athletics v. U.S. Dept. of Education, 504 F.Supp.2d 88 (W.D.Va. 2007), aff'd 2008 WL 4104235 (4th Cir. August 20, 2008).

Estes, G. (2007, September 14). Football salaries take 10 percent of Tide sports budget. Retrieved September 24, 2007, from http://www.al.com/sec/mobileregister/index. ssf?/base/sports/1189761325208790.xml\&coll=3.

Favia v. Indiana University of Pennsylvania, 812 F.Supp. 578 (W.D. Pa. 1993).

Federal Rules of Civil Procedure 12(b)(1).

Foudy, J. (2003, February 20). Text of letter to the Title IX commission. USA Today. Retrieved on August 28, 2008 from http://www.usatoday.com/sports/college/2003-02-24-titleix-devarona-letter_x.htm. 
Fresno State University. (2006, August 9). Fresno State answers wrestling questions. Retrieved August 29, 2008 from http://gobulldogs.cstv.com/genrel/080906aab.html.

Fulks, D.L. (2005). Revenues and expenses of Divisions I and II intercollegiate athletics programs report. Indianapolis, IN: National Collegiate Athletic Association.

Fulks, D.L. (2008). Revenues and expenses of Divisions I intercollegiate athletics programs report. Indianapolis, IN: National Collegiate Athletic Association.

General Accounting Office. (2001). Four-year colleges' experiences adding and discontinuing teams. Washington, DC: US Government Printing Office.

Gonyo v. Drake University, 879 F.Supp. 1000 (S.D. Iowa 1995).

Grove City College v. Bell, 465 U.S. 555 (1984).

Haffer v. Temple University, 524 F.Supp. 531 (E.D.Pa.1981).

Hearings on H.Con. Res. 330 Before the House Subcommittee on Equal Opportunities of the Committee on Education and Labor, 94 ${ }^{\text {th }}$ Cong., $1^{\text {st }}$ Sess. At p. 58 (July 14, 1975).

HR 2127. Making appropriations for the Departments of Labor, Health and Human Services, and Education, and related agencies, for the fiscal year ending September 30, 1996, and for other purposes.

Hughes, J. (1999, April 16). 2 universities cut some men's teams: Brigham Young and U. of New Mexico cite need to be competitive in other sports, but some coaches blame Title IX. The Chronicle of Higher Education. Retrieved on October 7, 2007 from http:// www.ncaa.org/gender_equity/resource_materials/AdditionalMaterials/TwoUnivCutMensTeams-1999.pdf.

Isleboro School Comm. v. Califano, 593 F.2d 424 ( $1^{\text {st }}$ Cir.), cert. denied, 444 U.S. 972 (1979).

Javits Amendment, Sen. Conf. Rep. No. 1026, 93 ${ }^{\text {rd }}$ Cong., $2^{\text {nd }}$ Sess. 4271 (1974).

Joint Hearings before the Committee on Education, Labor, and Subcommittee on Civil and Constitutional Rights of the Committee on the Judiciary, (1985).

Junior College Dist. of St. Louis v. Califano, 597 F.2d 119 ( $8^{\text {th }}$ Cir. $)$, cert. denied, 444 U.S. 972 (1979).

Kelley v. Board of Trustees of the University of Illinois, 35 F.3d 265 ( $7^{\text {th }}$ Cir. 1994), cert. denied, 513 U.S. 1128 (1995).

Knight Commission. (2007). A call to action. Retrieved October 4, 2007, from http://www. knightcommission.org/about/a_call_to_action_ten years later/.

Lawrence, H.J., \& Li, M. (2007, March). Intercollegiate athletic spending: An examination of gender specific expenditures. Paper presented at the meeting of the Girls and Women Rock Symposium celebrating the $35^{\text {th }}$ Anniversary of Title IX, Cleveland, $\mathrm{OH}$.

Litan, R.E., Orszag, J.M., \& Orszag, P.R. (2003). The empirical effects of collegiate athletics: An interim report. Indianapolis, IN: National Collegiate Athletic Association.

Lopiano, D. (2001, May 9). Dropping men's sports - The Division I football/basketball arms race is the culprit in the cutting of men's Olympic sports: The Foundation position. Retrieved September 28, 2007, from http://www.womenssportsfoundation.org/ cgi-in/iowa/issues/rights/article.html?record=777.

Louisiana State University. (2007). Cox communications academic center for student- athletes. Retrieved October 4, 2007, from http://www.acsa.lsu.edu/about.htm.

McCormick v. School Dist. of Mamaroneck, 370 F.3d 275 (2 ${ }^{\text {nd }}$ Cir. 2004).

Miami University Wrestling Club v. Miami University of Ohio, 302 F.3d 608 ( $6^{\text {th }}$ Cir. 2002).

Munson, L. (2006, November 3). A taxing situation: NCAA following elections closely for fiscal implications. Retrieved October 30, 2007, from http://sportsillustrated .cnn. com/2006/writers/lester_munson/11/03/ncaa.tax/index.html 
NCAA v. Califano, 444 F.Supp. 425 (D. Kan. 1978).

National Coalition for Women and Girls in Education (2002, August). Title IX athletics policies: Issues and data for education decision makers. Washington, DC: Author.

National Collegiate Athletic Association. (2007a) Gender equity in intercollegiate athletics: A practical guide for colleges and universities. Retrieved September 20, 2007, from www.ncaa.org/library/general/gender_equity/gender_equity_manual.pdf.

National Collegiate Athletic Association (2007b). NCAA Division I legislative services database. Retrieved September 27, 2007, from https://goomer.ncaa.org/wdbctx/lsdbi/ LSDBi.LSDBiPackage.SearchBylawsAndDisplayList.

National Collegiate Athletic Association (2007c). Division I basketball fund. Retrieved October 4, 2007, from http://www1.ncaa.org/finance/5-yr_conf_summaries/basketball.

National Collegiate Athletic Association (2007d). History. Retrieved November 7, 2007, from http://www.ncaa.org/wps/portal/!ut/p/kcxml/04_Sj9SPykssy0xPLMnMz0vM0Y_QjzKLN4j3CQXJgFjGpvqRqCKOcAFfj_zcVH1v_QD9gtzQiHJHRUUAc0tpTA!!/delta/base64xml/L3dJdyEvUUd3QndNQSEvNEIVRS82XzBfTFU!?C ONTENT_URL=http://www.ncaa.org/about/history.html.

National Collegiate Athletic Association. (2000). Gender equity report. Indianapolis: NCAA.

National Collegiate Athletic Association. (2001). 1982-2001 Sports sponsorship and participation statistics report. Indianapolis; NCAA.

National Collegiate Athletic Association. (2003). Title IX Commission Report. Indianapolis: NCAA.

National Collegiate Athletic Association. (2007a). The National Collegiate Athletic Association Revised Budget for Fiscal Year Ended August 1, 2007. Retrieved October 15, 2007 from http://www1.ncaa.org/finance/2006-07_budget.pdf.

National Collegiate Athletic Association. (2007b). 2006-07 Revenue distribution plan. Retrieved October 15, 2007 from http://www1.ncaa.org/finance/revenue_distribution_plan.

National Collegiate Athletic Association. (2008). 2008-09 NCAA division I manual. Indianapolis: NCAA.

Neal v. Board of Trustees of Cal State University, 198 F.3d 763 (9th Cir. 1999).

National Wrestling Coaches Association v. Department of Education, 263 F.Supp.2d 82 (D.D.C. 2003), aff'd, 366 F.3d 930 (D.C. Cir. 2004), rehrg \& rehrg en banc denied, 383 F.3d 1047 (D.C.Cir. 2004), cert. denied, 545 U.S. 1104 (2005), rehrg denied, 545 U.S. 1154 (2005).

North Haven Board of Education v. Bell, 456 U.S. 512 (1982).

O’Connor v. Peru State College, 728 F.2d 1001, 1002 (8th Cir.1984).

Oregon to reinstate baseball, drop wrestling. (2007, July 13). The Oregonian. Retrieved August 29, 2008, from http://blog.oregonlive.com/sportsupdates/2007/07/oregon_to_ reinstate_baseball_p.html.

Orszag J., \& Orszag, P. (2005, April). The empirical effects of collegiate athletics: An update. Indianapolis, IN: National Collegiate Athletic Association.

Othen v. Ann Arbor School Board, 507 F.Supp. 1376 (E.D. Mich. 1981).

Pederson v. Louisiana State University, 213 F.3d 858 (5 ${ }^{\text {th }}$ Cir. 2000).

Reynolds, G. (2003, July). Further clarification of intercollegiate athletics policy guidance regarding Title IX compliance. Washington, DC: United States Department of Education Office of Civil Rights.

Ridpath, B. (2007a, April). Confessions of a former wrestling coach regarding the application of Title IX and the sport of wrestling. Paper presented at the meeting of the Girls and Women Rock Symposium celebrating the $35^{\text {th }}$ Anniversary of Title IX, Cleveland, $\mathrm{OH}$. 
Ridpath, B. (2007b, Fall). Factors that influence the academic performance of NCAA Division I athletes. Sport Management and Related Topics Journal (SMART), IV(1). Retrieved November 1, 2007, from http://www.thesmartjournal.com/volume4.htm.

Rimbach, J., \& Alex, P. (2006, November 5). The price of glory-Rutgers spends millions on football amid massive cuts, layoffs. The Record (Hackensack, NJ). Roberts v. Colorado State University, 814 F.Supp. 1507 (D.Colo. 1993), affd, 998 F.2d 824 (1993).

Roberts v. Colorado State Board, 998 F.2d 824 (10 ${ }^{\text {th }}$ Cir. 1993).

Robinson, A. (2008, August 15). American women back on mat without medal winners. Retrieved on August 28, 2008 from http://www.huaxlee.com/olympics/7006/american-women-back-on-mat-without-medal-.

Romeo Community Schools v. HEW, 438 F.Supp. 1021 (E.D. Mich. 1977).

Sack, A., \& Staurowsky, E. (1998). College athletes for hire: The evolution and legacy of the NCAA's amateur myth. Westport, CT: Praeger/Greenwood.

Seattle University v. HEW, 16 F.E.P. 719, aff'd, 621 F.2d 992 (9 $9^{\text {th }}$ Cir. 1980).

Senate Congressional Resolution 46, 121. (1975). Congressional Record, 17, 300.

Senate Congressional Resolution 52, 121. (1975). Congressional Record, 22, 940.

Senate Conf. Rep. No. 1026, $93^{\text {rd }}$ Cong., $2^{\text {nd }}$ Sess. 4271 (1974).

Senate Report No. 64, 100 $0^{\text {th }}$ Congress, $2^{\text {nd }}$ Session 4, reprinted in 1988 U.S.Code Congress \& Ad. News at pp. 3, 6. and 20 U.S.C. $\$ 1687$.

Smith, D. (2004, May 21). Women's wrestling reaches the Olympics. Women's eNews. Retrieved August 28, 2008 from http://www.womensenews.org/article.cfm/dyn/ aid/1840.

Splitt, F. (2004, July 13). The faculty driven movement to reform big-time college sports: Sequel to the brief reclaiming academic primacy in higher education. McCormick School of Engineering and Applied Science Report. Retrieved October 30, 2007, from www.thedrakegroup.org/Splitt_Sequel.pdf.

Staurowsky, E. (2003). The Title IX Commission's Flawed Lineup. The Journal of Physical Education. Recreation \& Dance,74(4), 5.

Suggs, W. (2003, May 2). Sports as the university's front porch? The public is skeptical [Electronic version]. The Chronicle of Higher Education. Retrieved October 9, 2007, from http://chronicle.com/weekly/v49/i34/34a01701.htm.

Suggs, W. (2005). A place on the team: The triumph and tragedy of Title IX. Princeton, NJ: Princeton University Press.

TheMat.com.TheOfficialWebsite ofUSAWrestling.(2008)RetrievedOctober30,2008, from http://www.themat.com/section.php?section_id=7\&page=display\&ArticleID=107.

Thomas, W. (2006, October 2). Letter to NCAA President Myles Brand. Washington DC: House Ways and Means Committee.

Title IX basics: Breaking down barriers, (2008). Retrieved on November 2, 2008 from http://www.nwlc.org/pdf/BDB07_Ch2.pdf.

University of Iowa. (2007). Fiscal Report FY 2007. Iowa City, IA.

Upton, J., \& Wieberg, S. (2006, November 16). Contracts for college coaches cover more than just salaries [Electronic version]. USA Today. Retrieved September 28, 2007, from http://www.usatoday.com/sports/college/football/2006-11-16-coaches-salariescover_x.htm.

U. S. Department of Education Office of Postsecondary Education. (2007). Equity in athletics disclosure act data. Office of Postsecondary Education. Retrieved October 8, 2007, from http://ope.ed.gov/athletics/search.asp.

Varsity women's wrestling teams. (2008). Retrieved August 29, 2008, from http://www. wrestlegirl.com/womensteams.htm.

Wolverton, B. (2007). The athletics department of the future. The Chronicle of Higher Education, 53(46), A28. 
Women's Sports Foundation. (2000, July 28). Gender equity, creative solutions-a case study in compliance. Retrieved September 25, 2007, from http://www.womenssportsfoundation.org/cgi-bin/iowa/issues/ rights/article.html?record=109.

Wright v. Columbia University, 520 F.Supp. 789 (E.D. Pa. 1981).

Yiamouyiannis, A. (2003). The future of Title IX: Ensuring success through proactive approaches. Women in Sport \& Physical Activity Journal, 12(2), 45-54.

Yuracko, K. (2002, April). Title IX and the problem of gender equality in athletics. Gender Issues, 20, p. 65-80. 